\title{
STRUKTUR MODAL PERUSAHAAN-PERUSAHAAN NON KEUANGAN YANG TELAH GO PUBLIC DI BURSA EFEK INDONESIA BERDASARKAN TRADE OFF THEORY
}

\author{
Oleh: \\ Dr. Donalson Silalahi
}

\begin{abstract}
This study aims, First, to obtain the empirical evidence about the capital structure of nonfinancial firms in Indonesia Stock Exchange. Second, to obtain the empirical evidence about the impact of capital structure on the value of non-financial firms in Indonesia Stock Exchange. Third, to obtain the empirical evidence about the impact of profitability, size of the firm, growth opportunity, the structure of assets, and the cost of bankruptcy to capital structure of non-financial firms in Indonesia Stock Exchange.

To achieve these objectives, conducted research on companies listed on the Indonesia Stock Exchange. Research conducted on 163 companies with the observation period in 2011. All the required data obtained from the Indonesian Capital Market Directory. Furthermore, to explain the determinants of capital structure of the firm to used the $t$ and F test with alpha 10 percent.

Based on the results of the study, the conclusions as follows: First, the capital structure of the firm has a negative and significant effect on the value of the firm. Second, there is no optimal capital structure on a non-financial corporations. Third, the size of the firm, the structure of assets, and the cost of bankruptcy have positive and significant effect on the capital structure of the firm. Fourth, profitability and the growth opportunities of the firm does not significantly influence to the capital structure. Fifth, variations in the profitability, size of the firm, growth opportunities, the structure of assets, and the cost of bankruptcy are able to explain the variations of capital structure 10,2 percent. Sixth, the coefficient towards research results influence the profitability and bankruptcy costs the company is not in accordance with the trade-offs theory.
\end{abstract}

Key Words: Trade-off theory, capital Structure, value of the firm.

\section{PENDAHULUAN}

Pada dasarnya manajer keuangan perusahaan melaksanakan tiga keputusan, yaitu: keputusan investasi, keputusan pembiayaan, dan keputusan dividen. Ketiga keputusan tersebut dilaksanakan untuk menciptakan nilai bagi shareholders (Van Horne: 1991). Dewasa ini, salah satu dari ketiga keputusan tersebut yang cukup pesat perkembangannya adalah keputusan pembiayaan atau struktur modal perusahaan.

Struktur modal perusahaan menggambarkan perbandingan antara utang dan ekuitas yang dipergunakan untuk membiayai hartanya. Teori keuangan modern dalam kaitannya dengan struktur modal disebut dengan irrelevance theory. Teori tersebut menyatakan bahwa keputusan pembiayaan perusahaan adalah given dengan nilai perusahaan (Modigliani dan Miller: 1958).

Semenjak irrelevance theory diperkenalkan, teori struktur modal telah berkembang pesat. Berdasarkan hasil review literatur, teori-teori yang berhubungan dengan struktur modal selain irrelevance theory, adalah: the trade-off theory, pecking order theory, agency theory, signaling theory, dan market timing theory. Masing-masing teori tersebut dibangun berdasarkan suatu aksioma serta maksud tertentu. Misalnya, the trade-off theory dibangun dalam rangka menjelaskan hubungan antara struktur modal dengan nilai perusahaan. Pecking order theory dibangun bukan 
untuk menjelaskan nilai perusahaan, tetapi lebih mengarah terhadap pilihan pembiayaan atas suatu investasi. Begitu juga halnya dengan teori struktur modal lainnya.

Struktur modal perusahaan mengalami perubahan dari tahun ke tahun. Kondisi ini menggambarkan adanya faktor-faktor yang dapat mempengaruhi perubahan struktur modal. Niu (2008) mengemukakan bahwa determinan struktur modal relatif banyak sesuai dengan perkembangan teori struktur modal. Lebih lanjut dikemukakan bahwa variabel determinan struktur modal yang sama antara suatu teori dengan teori yang lain memberikan arah prediksi yang berbeda. Oleh karenanya, sangat menarik dilakukan penelitian tentang struktur modal perusahaan sehingga dapat diketahui teori mana yang lebih sesuai dalam menjelaskan struktur modal suatu objek.

Hingga dewasa ini telah banyak dilakukan penelitian tentang struktur modal perusahaan. Christianti (2008); Yuliati (2011) mempergunakan pecking order theory dalam menjelaskan struktur modal perusahaan, Lumbantobing (2008) mempergunakan teori keagenan, teori kontingensi, teori trade-off dan teori pecking order dalam menjelaskan struktur modal perusahaan, Setyawan dan Frensidy (2012), mempergunakan market timing theory dalam menjelaskan struktur modal perusahaan. Lebih lanjut, Manurung (2012) melakukan penelitian tentang struktur modal optimal di Bursa Efek Indonesia. Hasil penelitiannya menunjukkan tidak ada struktur modal yang optimal di Bursa Efek Indonesia. Oleh karenanya dapat dikemukakan bahwa hasil penelitiannya tidak selaras dengan the trade-off theory.

Di sisi lain, Jahanzeb et al. (2014) mengemukakan bahwa the trade-off theory dan pecking order theory selalu mendominasi keputusan struktur modal. Artinya, kedua teori tersebut banyak dipergunakan untuk menjelaskan determinan struktur modal suatu perusahaan. Lebih lanjut, Huang dan Song (2003) menunjukkan bahwa determinan struktur modal berdasarkan the trade-off theory lebih baik dipergunakan dalam menjelaskan struktur modal perusahaan daripada pecking order theory.

Oleh karenanya, berdasarkan kedua pendapat tersebut dan dihubungkan dengan hasil penelitian yang dilakukan oleh Manurung (2012) tentang struktur modal di Indonesia, maka sangat penting dilakukan penelitian lanjutan tentang struktur modal perusahaan-perusahaan yang telah go-public dan determinannya di Bursa Efek Indonesia khususnya untuk perusahaanperusahaan non keuangan dari perspektif the trade-off theory.

Dengan berpedoman pada paparan tersebut, maka penelitian ini bertujuan untuk: Pertama, mendapatkan bukti empiris tentang struktur modal perusahaan-perusahaan non keuangan di Bursa Efek Indonesia. Kedua, mendapatkan bukti empiris tentang dampak struktur modal terhadap nilai perusahaan-perusahaan non keuangan di Bursa Efek Indonesia. Ketiga, mendapatkan bukti empiris tentang determinan struktur modal perusahaan-perusahaan non keuangan di Bursa Efek Indonesia.

\section{TINJAUAN PUSTAKA}

\section{Struktur Modal dan Nilai Perusahaan}

Hubungan antara struktur modal dengan nilai perusahaan telah diperdebatkan baik secara teoritis maupun empiris. Menurut Modigliani dan Miller (1958 dan 1963), dalam kondisi pasar modal sempurna, financial leverage independen terhadap nilai perusahaan. Artinya, financial leverage tidak berpengaruh terhadap nilai perusahaan. Sebaliknya, dalam kondisi pasar modal tidak sempurna, maka struktur modal berhubungan positip dengan nilai perusahaan. Hubungan positip terjadi karena perusahaan memperoleh manfaat penghematan pajak akibat pembayaran bunga atas utang-utang perusahaan. Oleh karenanya, perusahaan lebih baik meningkatkan utang dalam membiayai hartanya sebab dapat meningkatnya nilai perusahaan. 
Selanjutnya, Miller (1977) memasukkan personal taxes dalam model analisisnya dan menunjukkan bahwa penggunaan utang yang optimal terdapat pada level makro. Di samping hal tersebut, peneliti-peneliti lain menambahkan masalah ketidaksempurnaan pasar, seperti; biaya kebangkrutan (Litzenberger: 1973), biaya agensi (Jensen dan Meckling: 1976), dan keuntungan dari leverage termasuk tax shields (DeAngelo dan Masulis: 1980) dalam analisisnya, dan dikemukakan masih terdapat struktur modal yang optimal.

Lebih lanjut, Masulis (1983) mengemukakan bahwa tingkat utang yang optimum terjadi jika dampak dari marginal tax (a) sama dengan marginal cost atas penggunaan leverage (b), sehingga jika $\mathrm{a}>\mathrm{b}$, maka perusahaan dapat meningkatkan nilainya dengan meningkatkan utang dalam struktur modalnya. Sebaliknya, jika $a<b$, maka nilai perusahaan dapat dinaikkan dengan menurunkan utang dalam struktur modalnya. Berdasarkan paparan tersebut dapat dikemukakan terdapat struktur modal yang optimal. Artinya, pada rasio utang dengan ekuitas tertentu, nilai perusahaan maksimum.

\section{Determinan Struktur Modal}

Struktur modal suatu perusahaan mengalami perubahan dari suatu periode ke periode berikutnya. Perubahan tersebut menggambarkan adanya faktor-faktor yang mempengaruhi perubahan struktur modal. Oleh karenanya, perlu juga diperhatikan determinan yang mengakibatkan perubahan struktur modal tersebut. Hingga dewasa ini telah banyak dilakukan penelitian tentang determinan struktur modal. Hasil review literatur yang dilakukan oleh Chen (2003) menunjukkan bahwa determinan utama struktur modal adalah profitability, size, growth opportunity, asset structure, costs of financial distress, and tax shields effects.

Profitability merupakan kemampuan perusahaan dalam menghasilkan laba. Modigliani dan Miller (1958) menjelaskan bahwa perusahaan dengan profitabilitas yang tinggi akan menggunakan hutang sebagai pilihan pendanaannya untuk memperoleh manfaat penghematan pajak. Profitability suatu perusahaan dapat dijelaskan melalui hubungan antara laba dengan penjualan atau hubungan antara laba dengan harta (Hampton: 1983). Dengan demikian profitability dalam kaitannya dengan struktur modal dimanifestasikan oleh hubungan antara laba dengan harta. Dengan mengacu pada paparan tersebut, maka perusahaan yang lebih profitable (menguntungkan) akan memiliki leverage yang lebih tinggi disebabkan perusahaan tersebut memperoleh income atas shield pajak (Bauver: 2004).

Variabel kedua adalah size perusahaan. Menurut Hampton (1983), size perusahaan dimanifestasikan oleh jumlah harta atau nilai penjualan. Pada dasarnya, perusahaanperusahaan yang besar cenderung melakukan diversifikasi terhadap kegiatan usahanya sehingga kemungkinan perusahaan mengalami kegagalan semakin rendah. Lebih lanjut, perusahaan-perusahaan besar diharapkan memiliki kapasitas meminjam yang lebih besar sehingga risk of bankruptcy rendah. Dengan demikian harta perusahaan dapat dipergunakan untuk menggambarkan size perusahaan. Oleh karena itu, size perusahaan berhubungan positip dengan struktur modal.

Variabel ketiga adalah growth opportunities. Berdasarkan the trade-off theory, perusahaan yang memiliki growth opportunities di masa depan cenderung memiliki tangible assets yang lebih besar bila dibandingkan dengan intangible assets (Chen: 2003). Pada dasarnya, perusahaan yang tingkat pertumbuhannya tinggi, kemungkinan memiliki kemampuan untuk mendanai usahanya secara internal ketimbang secara eksternal. Oleh karena itu, perusahaan-perusahaan yang memiliki tingkat pertumbuhan tinggi kemungkinan memiliki rasio hutang yang rendah (Myers, 1977). Dengan demikian, dapat dipostulasikan bahwa tingkat pertumbuhan perusahaan berpengaruh negatif terhadap struktur modal perusahaan. 
Variabel keempat adalah tangibility (struktur aktiva). Tangible assets dapat dipergunakan sebagai agunan atas suatu pinjaman. Dengan demikian, tangible assets yang lebih tinggi dapat dipergunakan sebagai agunan atas suatu pinjaman sehingga risiko bagi kreditur semakin rendah. Oleh karenanya, hubungan antara tangible assets dengan leverage adalah positip (Bauver: 2004).

Variabel kelima adalah biaya kebangkrutan. Pada dasarnya, peningkatan hutang akan meningkatkan risiko keuangan dan peluang kegagalan keuangan. Oleh karenanya, risiko keuangan dan peluang kegagalan keuangan berkorelasi positif dengan penerbitan ekuitas, yang berarti semakin tinggi risiko keuangan, semakin membuat pendanaan dengan hutang bukan menjadi prioritas perusahaan. Dengan demikian dapat dikemukakan bahwa biaya kebangkrutan berpengaruh negatif terhadap struktur modal perusahaan.

Variabel keenam adalah tax (tax shields effects). Menurut the trade-off theory, perusahaan dengan tingkat pajak yang lebih besar akan mempergunakan utang yang lebih besar dan dengan demikian akan memiliki leverage yang lebih besar sebab penggunaan leverage tersebut akan menghasilkan pendapatan yang lebih banyak dari shield from taxes (Bauver: 2004).

\section{METODE PENELITIAN}

\section{Variabel Penelitian}

Dalam penelitian ini, variabel yang dipergunakan terdiri dari: nilai perusahaan (NP), struktur modal perusahaan (SMP), kuadratik struktur modal perusahaan (KSMP), kemampuan perusahaan menghasilkan laba (KPML), ukuran perusahaan (UP), peluang pertumbuhan perusahaan (PPP), struktur harta perusahaan (SHP), dan biaya kebangkrutan perusahaan (BKP).

Nilai perusahaan (NP) menggambarkan kekayaan pemilik perusahaan yang dimani festasikan oleh harga saham penutupan masing-masing perusahaan. Struktur modal perusahaan (SMP) menggambarkan struktur pembiayaan harta yang dimanifestasikan oleh rasio hutang dengan ekuitas dan kuadratik struktur modal perusahaan (KSMP) menggambarkan struktur pembiayaan perusahaan.

Kemampuan perusahaan menghasilkan laba (KPML) menggambarkan besaran laba operasi yang diperoleh atas setiap rupiah harta yang dimanifestasikan oleh rasio laba sebelum bunga dan pajak dengan jumlah harta. Ukuran perusahaan (UP) menggambarkan besar perusahaan yang dimanifestasikan oleh jumlah harta masing-masing perusahaan. Peluang pertumbuhan perusahaan (PPP) menggambarkan pertumbuhan perusahaan yang dimanifestasikan oleh rasio harga saham terhadap nilai buku masing-masing perusahaan.

Struktur harta perusahaan (SHP) menggambarkan besaran agunan yang dapat dipergunakan untuk melakukan pinjaman yang dimanifestasikan oleh rasio penjumlahan antara harta tetap dengan persediaan dengan jumlah harta perusahaan, dan biaya kebangkrutan perusahaan (BKP) menggambarkan kesulitan keuangan yang dihadapi oleh masing-masing perusahaan akibat semakin bertambah besarnya hutang yang dimilikinya dan dimanifestasikan oleh persentase perubahan laba operasi (absolute).

\section{Populasi dan Sampel Penelitian}

Populasi dalam penelitian ini adalah semua perusahaan-perusahaan non keuangan yang terdaftar di Bursa Efek Indonesia pada akhir tahun 2011. Jumlah perusahaan-perusahaan non keuangan yang terdaftar di bursa efek Indonesia pada akhir tahun 2011 sebanyak 256 perusahaan. Dengan mengeliminasi perusahaan-perusahaan yang baru mengemisikan 
sahamnya dan perusahaan-perusahaan yang sahamnya jarang diperdagangkan, maka sample size sebanyak 163 perusahaan. Dengan demikian, teknik pengambilan sampel dalam penelitian ini mempergunakan teknik purposive sampling (Indriantoro dan Supomo: 1999).

\section{Data dan Sumber Data}

Data yang dipergunakan dalam penelitian ini adalah data sekunder, yaitu: data nilai perusahaan (NP), struktur modal perusahaan (SMP), kuadratik struktur modal perusahaan (KSMP), kemampuan perusahaan menghasilkan laba (KPML), ukuran perusahaan (UP), peluang pertumbuhan perusahaan (PPP), struktur harta perusahaan (SHP), dan biaya kebangkrutan perusahaan (BKP) masing-masing perusahaan yang menjadi sampel penelitian dan terdaftar di Bursa Efek Indonesia pada 2011. Semua data tersebut didapatkan dari Indonesian Capital Market Directory Tahun 2011. Dengan demikian teknik pengambilan data dalam penelitian ini adalah teknik dokumentasi.

\section{Metode Analisis}

Untuk menguji hipotesis dipergunakan model sebagaimana ditunjukkan dalam persamaan berikut ini.

$\mathrm{NP}=\alpha+\beta_{1} \mathrm{SMP}+\varepsilon$

$\mathrm{NP}=\alpha+\beta_{1} \mathrm{SMP}+\beta_{2} \mathrm{KSMP}^{2}+\varepsilon$

$\mathrm{SMP}=\alpha+\beta_{1} \mathrm{KPML}+\beta_{2} \mathrm{UP}+\beta_{3} \mathrm{PPP}++\beta_{4} \mathrm{SHP}+\beta_{5} \mathrm{BKP}+\varepsilon$

Dimana NP merupakan nilai perusahaan, SMP merupakan struktur modal perusahaan, KSMP merupakan kuadratik struktur modal perusahaan, KPML merupakan kemampuan perusahaan menghasilkan laba, UK merupakan ukuran perusahaan, PPP merupakan peluang pertumbuhan perusahaan, SHP merupakan struktur harta perusahaan, dan BKP merupakan biaya kebangkrutan perusahaan.

Persamaan (1) dipergunakan untuk menguji pengaruh struktur modal perusahaan (SMP) terhadap nilai perusahaan (NP). Persamaan (2) dipergunakan untuk menguji struktur modal perusahaan (SMP) yang optimal serta sensitifitas nilai perusahaan (NP) terhadap dampak perubahan strutur modal perusahaan (SMP). Tingkat sensitifitas nilai perusahaan (NP) terhadap dampak perubahan struktur modal perusahaan (SMP) ditunjukkan oleh koefisien $\beta_{1}$, dan tingkat sensitifitas nilai perusahaan (NP) terhadap dampak perubahan kuadratik struktur modal perusahaan (KSMP) ditunjukkan oleh koefisien $\beta_{2}$.

Persamaan (3) dipergunakan untuk menguji sensitivitas struktur modal perusahaan (SMP) terhadap perubahan kemampuan perusahaan menghasilkan laba (KPML), ukuran perusahaan (UP), peluang pertumbuhan perusahaan (PPP), struktur harta perusahaan (SHP), dan biaya kebangkrutan perusahaan (BKP).

Tingkat sensitifitas struktur modal perusahaan (SMP) terhadap perubahan kemampuan perusahaan menghasilkan laba (KPML) ditunjukkan oleh koefisien $\beta_{1}$. Tingkat sensitifitas struktur modal perusahaan (SMP) terhadap perubahan ukuran perusahaan (UP) ditunjukkan oleh koefisien $\beta_{2}$. Tingkat sensitifitas struktur modal perusahaan (SMP) terhadap perubahan peluang pertumbuhan perusahaan (PPP) ditunjukkan oleh koefisien $\beta_{3}$. Tingkat sensitifitas struktur modal perusahaan (SMP) terhadap perubahan struktur harta perusahaan (SHP) ditunjukkan oleh koefisien $\beta_{4}$, dan Tingkat sensitifitas struktur modal perusahaan (SMP) terhadap perubahan biaya kebangkrutan perusahaan (BKP) ditunjukkan oleh koefisien $\beta_{5}$.

Untuk menjelaskan hubungan antara nilai perusahaan (NP) dengan struktur modal perusahaan (SMP), hubungan antara nilai perusahaan (NP) dengan struktur modal perusahaan (SMP) dan kuadratik struktur modal perusahaan (KSMP) serta hubungan antara struktur modal perusahaan (SMP) dengan kemampuan perusahaan menghasilkan laba (KPML), ukuran perusahaan 
(UP), peluang pertumbuhan perusahaan (PPP), struktur harta perusahaan (SHP), dan biaya kebangkrutan perusahaan (BKP) dipergunakan uji t dengan a sebesar 10 persen. Selanjutnya, untuk menjelaskan pengaruh secara serentak variabel bebas terhadap variabel tidak bebas dipergunakan uji $\mathrm{F}$ dengan a sebesar 10 persen serta untuk mengolah data dipergunakan program SPSS Version 18.

\section{HASIL PENELITIAN DAN PEMBAHASAN}

\section{Deskripsi Variabel Penelitian}

Deskripsi data yang berhubungan dengan nilai perusahaan (NP), struktur modal perusahaan (SMP), kuadratik struktur modal perusahaan (KSMP), kemampuan perusahaan menghasilkan laba (KPML), ukuran perusahaan (UP), peluang pertumbuhan perusahaan (PPP), struktur harta perusahaan (SHP), dan biaya kebangkrutan (BKP) masing-masing perusahaan yang menjadi sampel dalam penelitian ini dapat dilihat pada Tabel 1 berikut.

Tabel 2. Deskripsi Data Variabel Penelitian

\begin{tabular}{|l|r|r|r|r|r|}
\hline & $\mathrm{N}$ & Minimum & \multicolumn{1}{|c|}{ Maximum } & \multicolumn{1}{|c|}{ Mean } & \multicolumn{1}{c|}{ Std. Deviation } \\
\hline NP & 163 & 15.3500 & 120000.0000 & 4715.394785 & $1.4358947 \mathrm{E} 4$ \\
SMP & 163 & .0400 & 3.8800 & 1.112515 & .7881220 \\
KSMP & 163 & .0016 & 15.0544 & 1.855016 & 2.4695544 \\
KPML & 163 & -.1800 & .4244 & .094927 & .0993344 \\
UP & 163 & 28.0000 & 112857.0000 & 5303.441718 & $1.4060043 E 4$ \\
PPP & 163 & .0010 & 21.2000 & 2.251669 & 2.8658992 \\
SHP & 163 & .0007 & .9611 & .544575 & .2119509 \\
BKP & 163 & -.4268 & 49.5000 & 1.638723 & 5.7589625 \\
Valid N (listwise) & 163 & & & & \\
\hline
\end{tabular}

Sumber: Hasil Penelitian dan Sudah Diolah.

Pengaruh Struktur Modal Perusahaan dan Kuadratik Struktur Modal Perusahaan Terhadap Nilai Perusahaan

Untuk menjelaskan struktur modal perusahaan yang optimal dilihat dari pengaruh struktur modal perusahaan (SMP) dan kuadratik struktur modal perusahaan (KSMP) terhadap nilai perusahaan (NP). Namun demikian, sebelum struktur modal optimal ditentukan, terlebih dahulu dutentukan pengaruh struktur modal perusahaan (SMP) terhadap nilai perusahaan (NP). Rekapitulasi hasil perhitungan pengaruh struktur modal perusahaan (SMP) terhadap nilai perusahaan (NP) dapat dilihat pada Tabel 2 berikut ini.

Tabel 2. Rekapitulasi Hasil Penelitian Pengaruh Struktur Modal Perusahaan Terhadap Nilai Perusahaan

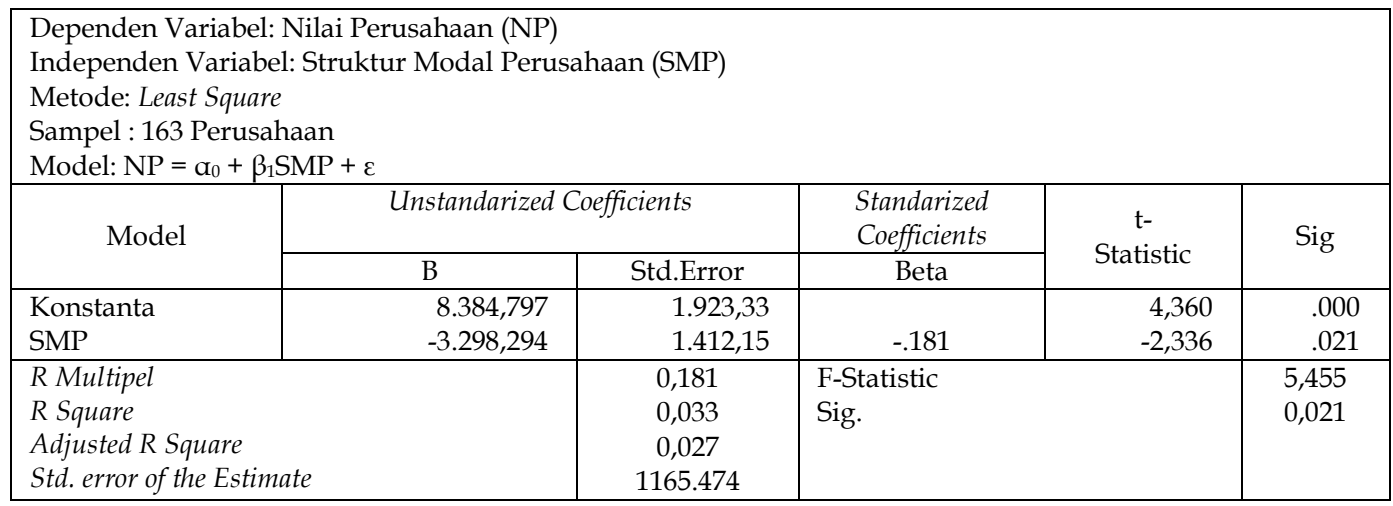

Sumber: Hasil Olahan Data Penelitian dengan Mempergunakan Program SPSS Version 18.

Berdasarkan Tabel 2 tersebut di atas, dapat dikemukakan bahwa nilai koefisien determinan sebesar 3,3 persen dengan nilai F-statistik adalah 5,455 dan probabilitas sebesar 
0,021. Selanjutnya, nilai koefisien regressi standardisasi variabel struktur modal perusahaan (SMP) sebesar - 0,181 dengan nilai t-satistik sebesar -2,336 dan probabilitas sebesar 0,021. Oleh karena itu, dapat dikemukakan bahwa struktur modal perusahaan (SMP) berpengaruh negatip dan signifikan terhadap nilai perusahaan (NP). Artinya, setiap kenaikan struktur modal perusahaan (SMP) akan menurunkan nilai perusahaan (NP), dan penurunan struktur modal perusahaan (SMP) akan menaikkan nilai perusahaan (NP).

Selanjutnya, rekapitulasi hasil perhitungan pengaruh struktur modal perusahaan (SMP) dan kuadratik struktur modal perusahaan (KSMP) terhadap nilai perusahaan (NP) dapat dilihat pada Tabel 3 berikut ini.

Tabel 3. Rekapitulasi Hasil Penelitian Pengaruh Struktur Modal Perusahaan dan Kuadratik Struktur Modal Perusahaan Terhadap Nilai Perusahaan

\begin{tabular}{|c|c|c|c|c|}
\hline \multicolumn{5}{|c|}{$\begin{array}{l}\text { Metode: Least Square } \\
\text { Sampel : } 163 \text { Perusahaan } \\
\text { Model: } \mathrm{NP}=\alpha_{0}+\beta_{1} \mathrm{SMP}+\beta_{2} \mathrm{KSMP}+\varepsilon\end{array}$} \\
\hline \multirow{2}{*}{ Model } & Unstandarized Coefficients & $\begin{array}{l}\text { Standarized } \\
\text { Coefficients }\end{array}$ & \multirow{2}{*}{$\begin{array}{c}\mathrm{t}- \\
\text { Statistic }\end{array}$} & \multirow{2}{*}{ Sig } \\
\hline & Std.Error & Beta & & \\
\hline Konstanta & 2752.309 & & 3.887 & .000 \\
\hline-8062.582 & 4295.621 & -0.443 & -1.877 & .062 \\
\hline 1609.704 & 1370.884 & 0.277 & 1.174 & .242 \\
\hline $\begin{array}{l}\text { R Multipel } \\
R \text { Square } \\
\text { Adjusted R Square } \\
\text { Std. error of the Estimate }\end{array}$ & $\begin{array}{c}0,203 \\
0,041 \\
0,029 \\
0,00014 \\
\end{array}$ & $\begin{array}{l}\text { F-Statistic } \\
\text { Sig. }\end{array}$ & & $\begin{array}{l}3,423 \\
0,035\end{array}$ \\
\hline
\end{tabular}

Sumber: Hasil Olahan Data Penelitian dengan Mempergunakan Program SPSS Version 18.

Berdasarkan Tabel 3 tersebut di atas, dapat dikemukakan bahwa nilai koefisien determinan sebesar 4,1 persen dengan nilai F-statistik adalah 3,423 dan probabilitas sebesar 0,035. Selanjutnya, nilai koefisien regressi standardisasi variabel struktur modal perusahaan (SMP) sebesar - 0,443 dengan nilai t-satistik adalah -1,877 dan probabilitas sebesar 0,062. Oleh karena itu, dapat dikemukakan bahwa struktur modal perusahaan (SMP) berpengaruh negatip dan signifikan terhadap nilai perusahaan (NP). Nilai koefisien regressi standardisasi variabel kuadratik struktur modal perusahaan (KSMP) sebesar 0,277 dengan nilai t-statistik adalah 1,174 dan probabilitas 0,242. Dengan demikian dapat dikemukakan bahwa kuadratik struktur modal perusahaan (KSMP) berpengaruh positif dan tidak signifikan terhadap nilai perusahaan (NP). Berdasarkan data tersebut dapat dikemukakan tidak terdapat struktur modal perusahaan (SMP) yang optimal pada periode penelitian.

Pengaruh Kemampuan Perusahaan Menghasilkan Laba, Ukuran Perusahaan, Peluang Pertumbuhan Perusahaan, Struktur Harta Perusahaan, dan Biaya Kebangkrutan Perusahaan Terhadap Struktur Modal Perusahaan

Rekapitulasi hasil perhitungan pengaruh kemampuan perusahaan menghasilkan laba (KPML), ukuran perusahaan (UP), peluang pertumbuhan perusahaan (PPP), struktur harta perusahaan (SHP), dan biaya kebangkrutan perusahaan (BKP) terhadap struktur modal perusahaan (SMP) dapat dilihat pada Tabel 4 berikut ini. 
Tabel 4. Rekapitulasi Hasil Penelitian Pengaruh Kemampuan Perusahaan Menghasilkan Laba, Ukuran Perusahaan, Peluang Pertumbuhan Perusahaan, Struktur Harta Perusahaan dan Biaya Kebangkrutan Perusahaan Terhadap Struktur Modal Perusahaan

\begin{tabular}{|c|c|c|c|c|c|}
\hline \multicolumn{6}{|c|}{ Dependen Variabel: Struktur Modal Perusahaan (SMP) } \\
\hline \multicolumn{6}{|c|}{$\begin{array}{l}\text { Independen Variabel: Kemampuan Perusahaan Menghasilkan Laba (KPML), Ukuran } \\
\text { Perusahaan (UP), Peluang Pertumbuhan Perusahaan (PPP), Struktur Harta } \\
\text { Perusahaan (SHP) dan Biaya Kebangkrutan Perusahaan (BKP) }\end{array}$} \\
\hline \multicolumn{6}{|c|}{ Metode: Least Square } \\
\hline \multicolumn{6}{|c|}{ Sampel : 163 Perusahaan } \\
\hline \multicolumn{6}{|c|}{ Model: SMP $=\alpha_{0}+\beta_{1} \mathrm{KPML}+\beta_{2} \mathrm{UP}+\beta_{3} \mathrm{PPP}+\beta_{4} \mathrm{SHP}+\beta_{5} \mathrm{BKP}+\varepsilon$} \\
\hline \multirow{2}{*}{ Model } & \multicolumn{2}{|c|}{ Unstandarized Coefficients } & Standarized & \multirow{2}{*}{$\begin{array}{c}\mathrm{t}- \\
\text { Statistic }\end{array}$} & \multirow{2}{*}{ Sig } \\
\hline & B & Std.Error & Beta & & \\
\hline Konstanta & $-0,275$ & 0,140 & & -1.970 & 0.051 \\
\hline KPML & $-0,048$ & 0,040 & $-0,093$ & -1.201 & 0.231 \\
\hline $\mathrm{UP}$ & 0,084 & 0,042 & 0,156 & 1,988 & 0.049 \\
\hline PPP & -0.041 & 0.056 & $-0,057$ & -0.726 & 0,469 \\
\hline SHP & 0,251 & 0,088 & 0,216 & 2,842 & 0.005 \\
\hline BKP & 0,082 & 0,044 & 0,144 & 1.874 & 0.063 \\
\hline \multicolumn{2}{|l|}{ R Multipel } & 0,319 & F-Statistic & & 3.547 \\
\hline \multicolumn{2}{|c|}{ R Square } & 0,102 & Sig. & & 0,005 \\
\hline \multicolumn{2}{|c|}{ Adjusted R Square } & 0,073 & & & \\
\hline \multicolumn{2}{|c|}{ Std. error of the Estimate } & 0,364 & & & \\
\hline
\end{tabular}

Sumber: Hasil Olahan Data Penelitian dengan Mempergunakan Program SPSS Version 18.

Berdasarkan Tabel 4 tersebut di atas, dapat dikemukakan bahwa nilai koefisien determinan sebesar 10,2 persen dengan nilai F-statistik adalah 3,547 dan probabilitas sebesar 0,005 . Selanjutnya, nilai koefisien regressi variabel kemampuan perusahaan menghasilkan laba (KPML) sebesar - 0,048 dengan nilai t-satistik adalah -1.201 dan probabilitas sebesar 0,231. Dengan demikian dapat dikemukakan bahwa kemampuan perusahaan menghasilkan laba (KPML) berpengaruh negatip dan tidak signifikan terhadap struktur modal perusahaan (SMP).

Nilai koefisien regressi variabel kedua, yaitu ukuran perusahaan (UP) sebesar 0,084 dengan nilai t-satistik adalah 1,988 dan probabilitas sebesar 0,049. Dengan demikian dapat dikemukakan bahwa ukuran perusahaan (UP) berpengaruh positip dan signifikan terhadap struktur modal perusahaan (SMP).

Variabel ketiga adalah peluang pertumbuhan perusahaan (PPP). Nilai koefisien regressi variabel peluang pertumbuhan perusahaan (PPP) sebesar -0,041 dengan nilai t-statistik adalah 0,726 dan probabilitas sebesar 0,649. Dengan demikian dapat dikemukakan bahwa peluang pertumbuhan perusahaan (PPP) tidak berpengaruh terhadap struktur modal perusahaan (SMP).

Variabel keempat adalah struktur harta perusahaan (SHP). Nilai koefisien regressi variabel struktur harta perusahaan (SHP) sebesar 0,251 dengan nilai t-satistik adalah 2,842 dan probabilitas sebesar 0,005. Dengan demikian dapat dikemukakan bahwa struktur harta perusahaan (SHP) berpengaruh positip dan signifikan terhadap struktur modal perusahaan (SMP).

Variabel kelima adalah biaya kebangkrutan perusahaan (BKP). Nilai koefisien regressi variabel biaya kebangkrutan perusahaan (BKP) sebesar 0,082 dengan nilai t-satistik adalah 1,874 dan probabilitas sebesar 0,063. Dengan demikian dapat dikemukakan bahwa biaya kebangkrutan perusahaan (BKP) berpengaruh positip dan signifikan terhadap struktur modal perusahaan (SMP). 


\section{Pembahasan}

Berdasarkan rekapitulasi hasil penelitian sebagaimana ditunjukkan pada Tabel 2 di atas dapat dikemukakan bahwa struktur modal perusahaan (SMP) berpengaruh negatip dan signifikan terhadap nilai perusahaan (NP). Setiap peningkatan struktur modal perusahaan (SMP) sebesar 1 satuan mengakibatkan nilai perusahaan (NP) turun sebesar 0,181 satuan. Pengaruh negatip struktur modal perusahaan (SMP) terhadap nilai perusahaan (NP) menggambarkan manfaat setiap penambahan utang dalam membiayai investasinya lebih rendah dari biaya mempergunakan utang tersebut. Oleh karenanya, dalam meningkatkan nilai perusahaan (NP) perlu diturunkan struktur modal perusahaan (SMP). Penurunan struktur modal perusahaan (SMP) dapat dilakukan dengan mengkonversi utang menjadi saham, atau menerbitkan saham baru. Selain hal tersebut, struktur modal perusahaan (SMP) dapat diturunkan melalui peningkatan pendanaan internal dengan meningkatkan laba ditahan.

Selanjutnya, berdasarkan rekapitusasi hasil penelitian sebagaimana ditunjukkan pada Tabel 3 di atas dapat dikemukakan bahwa struktur modal perusahaan (SMP) berpengaruh negatip dan signifikan terhadap nilai perusahaan (NP) serta kuadratik struktur modal perusahaan (KSMP) berpengaruh positip dan tidak signifikan terhadap nilai perusahaan (NP). Kondisi ini menggambarkan bahwa tidak terdapat struktur modal yang optimal pada perusahaan-perusahaan non keuangan di Bursa Efek Indonesia. Oleh karenanya, hasil penelitian ini tidak mendukung the trade-off theory. Artinya, marginal tax dan marginal cost atas penggunaan utang tidak sama tetapi marginal cost cenderung lebih besar dari marginal tax sehingga struktur modal perusahaan (SMP) berpengaruh negatip terhadap nilai perusahaan (NP). Dengan demikian, hasil penelitian ini mendukung hasil penelitian yang dilakukan oleh Manurung (2012). Hasil penelitiannya menunjukkan tidak ada struktur modal yang optimal di Bursa Efek Indonesia.

Dengan tidak terdapatnya struktur modal yang optimal, selanjutnya dilakukan juga pengujian atas determinan struktur modal dengan mempergunakan teori trade-off. Berdasarkan rekapitulasi hasil penelitian sebagaimana ditunjukkan pada Tabel 4 di atas dapat dikemukakan bahwa kemampuan perusahaan menghasilkan laba (KPML) berpengaruh negatip dan tidak signifikan terhadap struktur modal perusahaan (SMP). Hal ini ditunjukkan oleh nilai koefisien regressi variabel kemampuan perusahaan menghasilkan laba (KPML) sebesar -0,048 dengan probabilitas sebesar 0,231. Oleh karena itu, hasil penelitian tentang pengaruh kemampuan perusahaan menghasilkan laba (KPML) terhadap struktur modal perusahaan (SMP) tidak sesuai dengan teori trade-off.

Teori trade-off mengemukakan bahwa perusahaan dengan profitability yang tinggi akan menggunakan hutang sebagai pilihan pendanaannya untuk memperoleh manfaat penghematan pajak atas penggunaan utang. Dengan demikian, perusahaan yang lebih profitable akan memiliki struktur modal yang lebih tinggi disebabkan perusahaan tersebut memperoleh income atas shield pajak. Artinya, kemampuan perusahaan menghasilkan laba (KPML) berpengaruh positip terhadap struktur modal perusahaan (SMP).

Walaupun pengaruh kemampuan perusahaan menghasilkan laba (KPML) terhadap struktur modal perusahaan (SMP) tidak signifikan secara statistik, tetapi dengan memperhatikan koefisien arah pengaruh kemampuan perusahaan menghasilkan laba (KPML) terhadap struktur modal perusahaan (SMP) adalah negatip, kondisi ini menunjukkan bahwa pecking order theory juga dipergunakan oleh para manajer keuangan perusahaan-perusahaan non keuangan dalam menentukan struktur modal perusahaan (SMP) di Bursa Efek Indonesia. Dengan memperhatikan koefisien arah pengaruh kemampuan perusahaan menghasilkan laba (KPML) terhadap struktur modal perusahaan (SMP), maka hasil penelitian ini selaras dengan 
hasil penelitian yang dilakukan oleh Bauer (2004); Khrawish dan Khraiwesh (2010); Yuliani (2011). Hasil penelitiannya menunjukkan bahwa profitability berpengaruh negatip terhadap struktur modal perusahaan. Perusahaan yang memiliki kemampuan menghasilkan laba atas investasinya yang semakin besar mengganbarkan kemampuan perusahaan untuk membayar utang-utangnya semakin besar sehingga jumlah utang semakin kecil dan dengan demikian struktur modal perusahaan semakin rendah.

Selanjutnya, hasil penelitian menunjukkan bahwa ukuran perusahaan (UP) berpengaruh positip dan signifikan terhadap struktur modal perusahaan (SMP). Hal ini ditunjukkan oleh nilai koefisien regressi variabel ukuran perusahaan (UP) sebesar 0,084 dengan probabilitas sebesar 0,049. Hasil penelitian ini sesuai dengan yang diharapkan berdasarkan teori trade-off. Dalam teori trade-off dikemukakan bahwa perusahaan-perusahaan yang besar cenderung melakukan diversifikasi kegiatan usahanya sehingga kemungkinan perusahaan mengalami kegagalan semakin rendah. Lebih lanjut, perusahaan-perusahaan yang besar diharapkan memiliki kapasitas meminjam yang lebih besar sehingga risk of bankruptcy rendah. Oleh karena itu, ukuran perusahaan (UP) berpengaruh positip terhadap struktur modal perusahaan (SMP).

Hasil penelitian ini selaras dengan hasil-hasil penelitian yang dilakukan oleh Chen (2003); Bauer (2004); Khrawish dan Khraiwesh (2010). Hasil penelitiannya menunjukkan bahwa ukuran perusahaan (UP) berpengaruh positip dan signifikan terhadap struktur modal perusahaan (SMP).

Variabel berikutnya adalah peluang pertumbuhan perusahaan (PPP). Peluang pertumbuhan perusahaan (PPP) berpengaruh negatip dan tidak signifikan terhadap struktur modal perusahaan (SMP). Hal ini ditunjukkan oleh nilai koefisien regressi variabel peluang pertumbuhan perusahaan (PPP) sebesar - 0,041 dengan probabilitas sebesar 0,649. Dengan memperhatikan koefisien arah variabel peluang pertumbuhan perusahaan (PPP), hasil penelitian ini sesuai dengan yang diharapkan berdasarkan teori trade-off, hanya saja tidak signifikan secara statistik. Dengan memperhatikan koefisien arah variabel peluang pertumbuhan perusahaan (PPP), maka hasil penelitian ini selaras dengan hasil penelitian yang dilakukan oleh Bauer (2004). Hasil penelitiannya menunjukkan bahwa peluang pertumbuhan perusahaan (PPP) berpengaruh negatip terhadap struktur modal perusahaan (SMP).

Perusahaan yang memiliki peluang pertumbuhan perusahaan (PPP) di masa depan cenderung memiliki tangible assets yang lebih besar bila dibandingkan dengan intangible assets sehingga perusahaan yang memiliki tingkat pertumbuhan yang tinggi kemungkinan memiliki kemampuan untuk mendanai usahanya secara internal daripada secara eksternal. Oleh karena itu tingkat pertumbuhan perusahaan berpengaruh negatif terhadap struktur modal perusahaan. Ketidak signifikanan pengaruh peluang pertumbuhan perusahaan (PPP) terhadap struktur modal perusahaan (SMP) mungkin disebabkan telah terjadinya pergeseran pembiayaan perusahaan dari internal ke eksternal.

Variabel keempat adalah tangibility atau struktur harta perusahaan (SHP). Hasil penelitian menunjukkan bahwa struktur harta perusahaan (SHP) berpengaruh positip dan signifikan terhadap struktur modal perusahaan (SMP). Hal ini ditunjukkan oleh nilai koefisien regressi variabel struktur harta perusahaan (SHP) sebesar 0,251 dan probabilitas adalah 0,005. Dengan memperhatikan koefisien arah dari variabel struktur harta perusahaan (SHP) dapat dikatakan bahwa hasil penelitian ini sesuai dengan yang diharapkan teori trade-off. Tangible assets dapat dipergunakan sebagai agunan atas suatu pinjaman. Oleh karena itu, tangible assets yang lebih tinggi dapat dipergunakan sebagai agunan sehingga risiko bagi kreditur semakin rendah. Dengan demikian, hubungan antara tangible assets dengan struktur modal adalah positip. Hasil penelitian ini selaras dengan hasil penelitian yang dilakukan oleh Chen (2003). 
Hasil penelitiannya menunjukkan bahwa struktur harta perusahaan (SHP) berpengaruh positip dan signifikan terhadap struktur modal perusahaan (SMP).

Variabel kelima adalah biaya kebangkrutan perusahaan (BKP). Hasil penelitian menunjukkan bahwa biaya kebangkrutan perusahaan (BKP) berpengaruh positip dan signifikan terhadap struktur modal perusahaan (SMP). Hal ini ditunjukkan oleh nilai koefisien variabel biaya kebangkrutan perusahaan (BKP) sebesar 0,082 dengan probabilitas adalah 0,063. Dengan demikian, hasil penelitian ini tidak sesuai dengan yang diharapkan teori trade-off.

Pada dasarnya, peningkatan hutang akan meningkatkan risiko keuangan dan peluang kegagalan keuangan. Risiko keuangan dan peluang kegagalan keuangan berkorelasi positif dengan penerbitan ekuitas, yang berarti semakin tinggi risiko keuangan, semakin membuat pendanaan dengan hutang bukan menjadi prioritas perusahaan. Oleh karenanya, peluang kebangkrutan perusahaan berkorelasi positif dengan struktur modal optimal, sedangkan biaya kebangkrutan yang diproksi oleh risiko sebagai financial distress berpengaruh negatif terhadap struktur modal. Berdasarkan pada paparan tersebut maka dapat dikemukakan bahwa biaya kebangkrutan perusahaan (BKP) berpengaruh negatif terhadap struktur modal perusahaan.

\section{KESIMPULAN DAN SARAN}

\section{Kesimpulan}

Berdasarkan hasil analisis dan pembahasan dapat dikemukakan beberapa kesimpulan sebagai berikut: Pertama, struktur modal perusahaan berpengaruh negatip dan signifikan terhadap nilai perusahaan. Kedua, tidak terdapat struktur modal yang optimal pada perusahaan-perusahaan non keuangan yang diamati. Ketiga, ukuran perusahaan, struktur harta perusahaan, dan biaya kebangkrutan perusahaan berpengaruh positip dan signifikan terhadap struktur modal perusahaan. Keempat, kemampuan perusahaan menghasilkan laba dan peluang pertumbuhan perusahaan tidak berpengaruh signifikan terhadap struktur modal perusahaan. Kelima, variasi kemampuan perusahaan menghasilkan laba, ukuran perusahaan, peluang pertumbuhan perusahaan, struktur harta perusahaan, dan biaya kebangkrutan perusahaan mampu menjelaskan variasi struktur modal perusahaan sebesar 10,2 persen. Keenam, koefisien arah hasil penelitian pengaruh kemampuan perusahaan menghasilkan laba dan biaya kebangkrutan perusahaan terhadap struktur modal tidak sesuai dengan teori trade-off.

\section{Saran}

Berdasarkan kesimpulan di atas dapat dikemukakan beberapa saran sebagai berikut: Pertama, variabel-variabel independen dalam penelitian ini hanya mempergunakan teori tradeoff sehingga untuk penelitian selanjutnya perlu memasukkan variabel-variabel independen lain berdasarkan teori struktur modal lainnya sehingga terdapat pemahaman yang lebih konprehensif tentang struktur modal perusahaan. Kedua, ukuran perusahaan, struktur harta perusahaan, dan biaya kebangkrutan perusahaan merupakan variabel penting dalam menentukan struktur modal perusahaan. 


\section{DAFTAR PUSTAKA}

Bauer, Patrik, 2004, Determinants of Capital Structure, Czech Journal of Economics and Finance, 54, $1-21$.

Chen, Jean J., 2003. Determinants of Capital Structure of Chinese-listed Companies, Journal of Business Research 57, 1341 - 1351.

Christianti, Ari, 2008. Pengujian Pecking Order Theory (POT): Pengaruh Leverage terhadap Pendanaan Surplus dan Deficit pada Industry Manufaktur di Bursa Efek Indonesia, The 2nd National Conference UKWMS Surabaya, 6 September 2008.

DeAngelo, H. and R. Masulis, 1980. Optimal Capital Structure under Corporate and Personal Taxation, Journal of Financial Economics 8, 3-29.

Hampton, John J. 1983. Financial Decision Making, Concepts, Problems, \& Cases, Prentice-Hall of India Private Limited New Delhi.

Huang, Samuel G.H and Frank M. Song, 2003. The Determinant of Capital Structure: Evidence from China, School of Economics and Finance and Centre for China Financial Research (CCFR), The University of Hong Kong, Pokfulam Road, Hong Kong.

Indriantoro, Nur dan Bambang Supomo, 1999. Metodologi Penelitian Bisnis untuk Akuntansi dan Manajemen, Edisi Pertama, BPFE, Yogyakarta.

Institute for Economic and Financial Research, 2011. Indonesian Capital Market Directory, Jakarta.

Jahanzeb, Agha; Saif-Ur-Rehman; Norkhairul Hafiz Bajuri; Meisam Karami, Aiyoub Ahmadimousaabad, 2014. Trade-Off Theory, Pecking Order Theory and Market Timing Theory: A Comprehensive Review of Capital Structure Theories, International Journal of Management and Commerce Innovations 1, 11 - 18.

Jensen, Michael C. and William H. Meckling, 1976. Theory of the Firms: Managerial Behavior, Agency Costs and Ownership Structure, Journal of Financial Economics 3, 305-360.

Khrawish, Husni Ali and Khraiwesh, Ali Husni Ali, 2010, The Determinants of the Capital Structure from Jordanian Industrial Companies, JKAU: Econ \& Adm., Vol. 24 No.1. pp. $173-196$

Lumbantobing, Rudolf, 2008. Studi mengenai Perbedaan Struktur Modal Perusahaan Penanaman Modal Asing dengan Perusahaan Penanaman Modal Dalam Negeri yang Go Public di Pasar Modal Indonesia (Perspektif Teori Dasar Struktur Modal, Teori Keagenan dan Teori Kontingensi dalam upaya mengoptimalkan Struktur Modal Perusahaan), Disertasi, Universitas Diponegoro, Semarang.

Manurung, Adler Haymans, 2012. Struktur Capital Optimal Perusahaan Manufaktur di BEI, Journal of Capital Market and Banking, 1, 1 - 19.

Masulis, R.W., 1983. The Impact of Capital Structure Change on Firm Value: Some Estimates, Journal of Finance 38, 107-126.

Miller, Merton, 1977. Debt and Taxes, Journal of Finance 32, 261-275.

Modigliani, F., and M.H. Miller, 1958. The Cost of Capital, Corporate Finance and the Theory of Investment, American Economic Review 48, 261-296. 
Modigliani, F., and M.H. Miller, 1963. Taxes and the Cost of Capital: A Correction, American Economic Review 53, 433-443.

Niu, Xiaoyan, 2008. Theoretical and Practical Review of Capital Structur and its Determinans, International Journal of Business and Management, March, 133 - 139.

Setyawan, Ignatius Roni; Budi Frensidy, 2012. Empirical Tests for Market Timing Theory of Capital Structure in Indonesia Stock Exchange, Paper submitted to the $20^{\text {th }}$ Annual Conference on Pasific Basic Finance, Economis, Accounting and Management 8-9 September 2012, Rutgers University, USA.

Van Horne, James C. 1991. Financial Management and Policy, Eighth Edition, Prentice-Hall of India Private Limited New Delhi.

Yuliati, Sri, 2011, Pengujian Pecking Order Theori: Analisis Faktor-Faktor Yang Mempengaruhi Struktur Modal Industri Manufaktur Di BEI Setelah Krisis Moneter, Politekno Sains X No.1, $56-69$. 